\title{
Coordination properties of Palladium(II) complex taken as a model of an antitumour agent with some selected amino acids, peptides and DNA constituents.
}

\author{
Ayser Al-Alousi ${ }^{a}$, Perihan A. Khalf-Alla ${ }^{a}$, Safaa S. Hassan ${ }^{a}$ and Mohamed M. Shoukry ${ }^{a, b}$ \\ ${ }^{a}$ Faculty of Science, Chemistry Department, Cairo University, P.O. Box 12611,Egypt. \\ ${ }^{b}$ Department of Chemistry, Faculty of Science, Islamic University, Madina, Saudi Arabia. \\ *Author for corresponding. E-mail address: shoukrymm@hotmail.com (MM Shoukry)
}

\begin{abstract}
$\mathrm{Pd}(\mathrm{DHP}) \mathrm{Cl}_{2}$ complex ( DHP = 1,3-diamino-2-hydroxopropane ), was synthesized and characterized by physico-chemical measurements. The coordination of $[\mathrm{Pd}(\mathrm{DHP})(\mathrm{H} 2 \mathrm{O}) 2] 2+$ with some selected bio-relevant ligands as phenylglycine, phenylalanine, lysine, valine, ethanolamine, glycineamide, glycylphenylalanine, glycylleucine, inosine, guanosine and inosine-5'-monophosphate disodium salt was investigated. Stoichiometry and stability constants of the complexes formed are reported at $25{ }^{\circ} \mathrm{C}$ and $0.1 \mathrm{M}$ ionic strength. The results show the formation of $1: 1$ complexes with amino acids. DNA constituents form 1:1 and 1:2 complexes. Peptides form both 1:1 complexes and the coresponding deprotonated amide species. The effect of chloride ion concentration on the formation constant of inosine, taken as a representaive of DNA constituents, complex with $\mathrm{Pd}(\mathrm{DPH})^{2+}$ was reporte
\end{abstract}

KEW WORDS: Coordination property; amino acids; peptides; DNA; 1,3-diamino-2-hydroxopropane and stability constants.

\section{Council for Innovative Research}

Peer Review Research Publishing System

Journal: Journal of Advances in Chemistry

Vol. 9, No. 3

editorjaconline@gmail.com

www.cirworld.org/journals 


\section{Introduction}

In 1969, Barnet Rosenberg discovered the cytostatic activity of cis- diamminedichloroplatinum(II)- cisplatin- by chance [1]. Cisplatin is nowadays used worldwide in the treatment of testicular and ovarial cancer and is increasingly used against cervical, bladder, and head/neck tumors [2]. Following the example of cisplatin, thousands of platinum -containing compounds have been synthesised and evaluated as potential antitumor drugs but only a few compounds reached clinical applications, viz. carboplatinn or oxaliplatin [3]. The development of new platinum compounds always continues, in the hope to supress side effects, to overcome drug resistance during therapy and to afford a broader range of applications [4]. As known for several years [5], a subsequent reaction with DNA will occur inside the nucleus, which results in a kink in the DNA structure and consequently leads to apoptosis of the cell or to reparation of the DNA by cutting out platinum and resynthesizing at the open sites [6]. This possibility of reparation of the platinated DNA leads to drug resistance and big efforts are still made to create novel platinum-containing compounds to reduce such cisplatin and carboplatin resistence, which may also violate the classical structure-activity relationship $[7,8]$. Therefore the thermodynamics of the reactions for the $\mathrm{Pt}$ (II) complexes is of great interest. In order to avoid the inert substitution behavior of $\mathrm{Pt}$ (II) complexes, and on the basis of the remarkable analogy between the coordination chemistry of $\mathrm{Pt}(\mathrm{II})$ and $\mathrm{Pd}(\mathrm{II})$ complexes, a series of labile $\mathrm{Pd}(\mathrm{II})$ complexes have proved useful as models for the $\mathrm{Pt}(\mathrm{II})$ complexes.

Work in our laboratories focused on the studies of metal complexes of biological significance [9-15]. Pd(II) complexes with bidentate amine forming five-membered chelate ring were extensively investigated as a model of the antitumor cis-diaminePt(II) complex. The palladium(II) complexes with 1,3-diamino-2-hydroxopropane involves a sixmembered chelate ring. The increase in the chelate ring size will increase the bite angle, which have an effect of increasing the steric interaction between the guanines in the cis- $\mathrm{Pt}\left(\right.$ diamine) $\mathrm{G}_{2}$ adduct, thereby slowing down the rotation of the guanines about the Pt- $\mathrm{N}_{7}$ bonds $[16,17]$. Such restrication may stabilize the DNA adduct. The is on line with the finding that cis- $\mathrm{Pt}(1,4-\mathrm{DACH}) \mathrm{Cl}_{2},(1,4-\mathrm{DACH}=1,4$-diaminocyclohexane $)$ where a seven-membered chelate ring is formed, is more active than cisplatin and oxaliplatin in several in vivo and in vitro tests [18]. Also, the $\mathrm{OH} g$ roup may undergo hydrogen bonding with DNA. Such effects may favor the interaction with DNA, which is the main target for the antitumor agent. For these reasons, it seems therefore of considerable interest to perform a systematic study of the complex formation equilibria between $\left[\mathrm{Pd}(\mathrm{DHP})\left(\mathrm{H}_{2} \mathrm{O}\right)_{2}\right]^{2+}$ and amino acids, peptides, dicarboxylic acids or DNA constituents.

\section{Experimental}

\subsection{Materials}

$\mathrm{PdCl}_{2}$ and 1,3-diamino-2-hydroxopropane (DHP) were provided by Aldrich Chem. Co. The ligands investigated are phenylglycine, phenylalanine, lysine, valine, ethanolamine, glycineamide, glycylphenylalanine, glycylleucine, inosine, guanosine, inosine-5'-monophosphate and 2-mercaptoethylamine. These materials were obtained from Sigma Chemical company and used without further purification. Guanosine, inosine-5'-monophosphate and were prepared in the protonated form with standard $\mathrm{HNO}_{3}$ solution. $\mathrm{Pd}(\mathrm{DHP}) \mathrm{Cl}_{2}$ was converted into the diaqua complex by treating it with two equivalents of $\mathrm{AgNO}_{3}$ as described before [9]. Carbonate- free $\mathrm{NaOH}$ (titrant) was prepared and standardized against potassium hydrogen phthalate solution daily. All solutions were prepared in deionized $\mathrm{H}_{2} \mathrm{O}$.

\subsection{Synthesis}

$\mathrm{Pd}(\mathrm{PHD}) \mathrm{Cl}_{2}$ was prepared by dissolving $\mathrm{K}_{2} \mathrm{PdCl}_{4}(2.82 \mathrm{mmol})$ in $10 \mathrm{ml}$ water with stirring. The clear solution of $\left[\mathrm{PdCl}_{4}\right]^{2-}$ was filtered and 1,3-diamino-2-hydroxopropane $(2.82 \mathrm{mmol})$, dissolved in $10 \mathrm{ml} \mathrm{H}_{2} \mathrm{O}$ was added drop wise to the stirred solution. The $\mathrm{pH}$ was adjusted to $2-3$ by the addition of $\mathrm{HCl}$ and/or $\mathrm{NaOH}$. A yellowish -brown precipitate of $\mathrm{Pd}(\mathrm{DHP}) \mathrm{Cl}_{2}$ was formed and stirred for a further 30 minute at $50{ }^{\circ} \mathrm{C}$. After filtering off the precipitate, it was thoroughly washed with $\mathrm{H}_{2} \mathrm{O}$, ethanol and diethyl ether. A yellow powder was obtained. Anal. Calcd. for $\mathrm{C}_{3} \mathrm{H}_{10} \mathrm{~N}_{2} \mathrm{OPdCl}_{2}(267.3): \mathrm{C}$, 13.6; $\mathrm{H}, 3.7$; N, 10.5. Found: C, 13.5; $\mathrm{H}, 4.0 ; \mathrm{N}, 10.3 \%$.

The IR spectrum of the $\mathrm{Pd}(\mathrm{DHP}) \mathrm{Cl}_{2}$ complex shows a sharp band at $3414 \mathrm{~cm}^{-1}$ for stretching vibration of $\mathrm{OH}$ group and distinct bands at $3050-3250 \mathrm{~cm}^{-1}$, which can assigned to stretching vibrations of $\mathrm{NH}_{2}$ group. The complex exhibits a band for $\left(\mathrm{NH}_{2}\right)$ bending at $1570 \mathrm{~cm}^{-1}$ and a band for the stretching vibration corresponding to $\mathrm{Pd}-\mathrm{N} \mathrm{at} 424 \mathrm{~cm}^{-1}$. The ligands in the form of hydrochlorides were converted to the corresponding hydronitrate in the same way as described above

\subsection{Apparatus}

Potentiometric titrations were performed with a Metrohm 686 titroprocessor equipped with a 665 Dosimat (Switzerland-Herisau). The titroprocessor and electrode were calibrated daily with standard buffer solutions prepared according to NBS specifications at $25.0 \pm 0.1^{\circ} \mathrm{C}[19]$ and I $=0.1 \mathrm{~mol}^{-\mathrm{dm}^{-3}}$, potassium hydrogen phthalate $(\mathrm{pH} 4.008)$ and 
a mixture of $\mathrm{KH}_{2} \mathrm{PO}_{4}$ and $\mathrm{Na}_{2} \mathrm{HPO}_{4}(\mathrm{pH}$ 6.865). A thermostated glass-cell was used equipped with a magnetic stirring system, a Metrohm glass-calomel combined electrode, a thermometric probe and a microburete delivery tube. Elemental microanalyses of the separated solid for $\mathrm{C}, \mathrm{H}$ and $\mathrm{N}$ was performed in the Microanalytical Center, Cairo University. The analyses were performed twice to check the accuracy of the analyses data.

\subsection{Procedure and Measuring Techniques}

The acid dissociation constants of the ligands were determined by titrating 1 mmole samples of each with standard $\mathrm{NaOH}$ solutions. Ligands were converted into their protonated form with standard $\mathrm{HNO}_{3}$ solutions. The acid dissociation constants of the coordinated water molecules in $\left[\mathrm{Pd}(\mathrm{DHP})\left(\mathrm{H}_{2} \mathrm{O}\right)_{2}\right]^{2+}$ were determined by titrating 1 mmole of complex with standard $0.05 \mathrm{M} \mathrm{NaOH}$ solution. The formation constants of the complexes were determined by titrating solution mixtures of $\left.[\mathrm{PdDHP})\left(\mathrm{H}_{2} \mathrm{O}\right)_{2}\right]^{2+}(1 \mathrm{mmole})$ and the ligand in the concentration ratio of 1:1 for amino acids, peptides and dicarboxylic acids and in the ratio of 1:2 (Pd:ligand) for the DNA constituents. The titrated solution mixtures each had a volume of 40 $\mathrm{ml}$ and the titrations were carried out at $25^{\circ} \mathrm{C}$ and $0.1 \mathrm{M}$ ionic strength (adjusted with $\mathrm{NaNO}_{3}$ ), $\mathrm{A}$ standard $0.05 \mathrm{M} \mathrm{NaOH}$ solution was used as titrant. The $\mathrm{pH}$ meter readings were converted into hydrogen ion concentration by titrating a standard acid solution $\left(0.05 \mathrm{~mol}_{-1 \mathrm{~m}^{-3}}\right)$, the ionic strength of which was adjusted to $0.1 \mathrm{~mol}-\mathrm{dm}^{-3}$, with standard base solution (0.05 mol- $-\mathrm{dm}^{-3}$ ) at $25^{\circ} \mathrm{C}$. The $\mathrm{pH}$ is plotted against $\mathrm{p}[\mathrm{H}]$. The relationship $\mathrm{pH}-\mathrm{p}[\mathrm{H}]=0.05$ was observed. $\left[\mathrm{OH}^{-}\right]$value was calculated using a $\mathrm{pK}_{\mathrm{w}}$ value of 13.997 [20]. The ionic strength was adjusted to $0.1 \mathrm{~mol}-\mathrm{dm}^{-3}$ by using $\mathrm{NaNO}_{3}$

The species formed were characterized by the general equilibrium

$$
\mathrm{pM}+\mathrm{qL}+\mathrm{rH} \rightleftharpoons(\mathrm{M})_{\mathrm{p}}(\mathrm{L})_{\mathrm{q}}(\mathrm{H})_{\mathrm{r}}
$$

for which the formation constants are given by

$$
\beta_{\mathrm{pqr}}=\frac{\left[(\mathrm{M})_{\mathrm{p}}(\mathrm{L})_{\mathrm{q}}(\mathrm{H})_{\mathrm{r}}\right]}{[\mathrm{M}]^{\mathrm{p}}[\mathrm{L}]^{\mathrm{q}}[\mathrm{H}]^{\mathrm{r}}}
$$

where $\mathrm{M}, \mathrm{L}$ and $\mathrm{H}$ stand for $\left[\mathrm{Pd}(\mathrm{DHP})\left(\mathrm{H}_{2} \mathrm{O}\right)_{2}\right]^{2+}$ ion, ligand and proton, respectively. The calculations were performed using the computer program [21] MINIQUAD-75. The stoichiometry and stability constants of the complexes formed were determined by trying various possible composition models for the systems studied. The model selected was that which gave the best statistical fit and was chemically consistent with the magnitudes of various residuals, as described elsewhere [21]. Tables (I-IV) list the stability constants together with their standard deviations and the sum of the squares of the residuals derived from the MINIQUAD output. The concentration distribution diagrams were obtained with the program SPECIES [22] under the experimental condition used.

\subsection{Spectrophotometric measurements}

Spectrophotometric measurements of $\mathrm{Pd}(\mathrm{DHP})$-glycinamide complex were performed by recording the UV-Visible spectra of solutions $(\mathrm{A}-\mathrm{C})$, where $(\mathrm{A})=1 \mathrm{mM}$ of $\mathrm{Pd}(\mathrm{DHP})\left(\mathrm{H}_{2} \mathrm{O}\right)_{2}{ }^{2+} ;(\mathrm{B})=1 \mathrm{mM}$ of PdDHP $)\left(\mathrm{H}_{2} \mathrm{O}\right)_{2}{ }^{2+}+1 \mathrm{mM}$ of glycylglycine $+1 \mathrm{mM}$ of $\mathrm{NaOH}$ and $(\mathrm{C})=1 \mathrm{mM}$ of $\mathrm{Pd}(\mathrm{DHP})\left(\mathrm{H}_{2} \mathrm{O}\right)_{2}{ }^{2+}+1 \mathrm{mM}$ of glycylglycine $+2 \mathrm{mM}$ of $\mathrm{NaOH}$. Under these prevailing experimental conditions and after neutralization of the hydrogen ions released, associated with complex formation, it is supposed that the complexes have been completely formed. In each mixture the volume was brought to 10 $\mathrm{ml}$ by addition of deionized water and ionic strength is kept constant at $0.1 \mathrm{M} \mathrm{NaNO}_{3}$.

\section{Results and discussion}

\subsection{Acid- base equilibria}

The acid dissociation constants of the ligands were determined under the experimental conditions of $(25 \pm 0.1)^{\circ} \mathrm{C}$ and a constant ionic strength of $0.1 \mathrm{~mol}-\mathrm{dm}^{-3}$, which were also used to determine the stability constants of the Pd(II) complexes. The values obtained are consistent with data reported in the literature [23,24].

The acid-base equilibria of the $\left[\mathrm{Pd}(\mathrm{DPH})\left(\mathrm{H}_{2} \mathrm{O}\right)_{2}\right]^{2+}$ complex is characterized by fitting the potentiometric data to various models. The best fit model was found to be consistent with the species 10-1 and 10-2 as given in Eq. (3) and the negative numbers refer to proton loss.

$\left[\mathrm{Pd}(\mathrm{DHP})\left(\mathrm{H}_{2} \mathrm{O}\right)_{2}\right]^{2+} \rightleftharpoons\left[\mathrm{Pd}(\mathrm{DHP})\left(\mathrm{H}_{2} \mathrm{O}\right)(\mathrm{OH})\right]^{+}+\mathrm{H}^{+}$

100
$10-1$ 


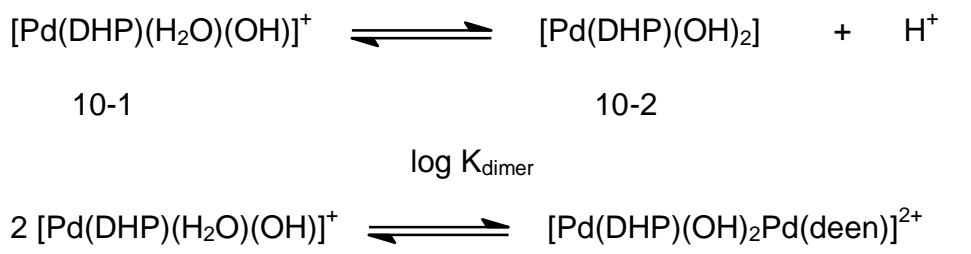

$20-2$

The $\mathrm{pK}_{\mathrm{a} 1}$ and $\mathrm{pK}_{\mathrm{a} 2}$ values were found to be 5.61 and 9.92 , respectively. The $\mathrm{pK}_{\mathrm{a} 1}$ value is higher than that for $\left[\mathrm{Pd}(\mathrm{AMBI})\left(\mathrm{H}_{2} \mathrm{O}\right)_{2}\right]^{2+}\left(\mathrm{pK}_{\mathrm{a}} 4.7\right)[25] \quad(\mathrm{AMBI}=2$-aminomethylbenzimidazole). This shows that the first coordinated water molecule in $\left[\mathrm{Pd}(\mathrm{DHP})\left(\mathrm{H}_{2} \mathrm{O}\right)_{2}\right]^{2+}$ is less acidic than that of $\left[\mathrm{Pd}(\mathrm{AMBI})\left(\mathrm{H}_{2} \mathrm{O}\right)_{2}\right]^{2+}$. This is attributed to the $\pi-$ acceptor properties of the aromatic moieties of $\mathrm{AMBI}$, which leads to an increase in the electrophilicity of the $\mathrm{Pd}(\mathrm{II})$ ion and consequently decreases the $\mathrm{pK}_{\mathrm{a}}$ of the coordinated water molecule. The mono-hydroxo- species (10-1) undergoes dimerization as given in Eq. 3. The equilibrium constant for the dimerization reaction can be calculated [14] by equation (4) and amounts to 3.72 .

$$
\log K_{\text {dimer }}=\log \square_{20-2}-2 \log \square_{10-1}
$$

\subsection{Complex Formation Equilibria Involving Amino Acids}

Fitting of $\mathrm{pH}$ titration data for $\mathrm{Pd}(\mathrm{DHP})$-amino acid equilibria indicated the formation of $1: 1$ complexes with high stability constant values. This reveals that amino acids bind through the amino and carboxylate groups. Threonine has an extra binding center on the $\beta$-alcoholate group. This group was reported $[26,27]$ to participate in transition metal ion complex formation reactions. The $\mathrm{pK}_{\mathrm{a}}$ value of the alcoholate group incorporated in the $\mathrm{Pd}(\mathrm{II}) \operatorname{complex}\left(\log \beta_{110}-\log \beta_{11-1}\right)$ is 8.71. Therefore in physiological $\mathrm{pH}(7.4)$, the $-\mathrm{OH}$ group participates in bonding with $\mathrm{Pd}(\mathrm{DHP})^{2+}$ ion.

The stability constant of lysine complex is higher than those of simple amino acids. This indicates that lysine coordinates via the two nitrogen centres, i.e. by the two amino groups. This is in line with the strong affinity of Pd(II) ion for nitrogen donor centres. It is to be reported that the bulky groups around the coordination centres as in phenylglycine, phenylalanine and valine has no effect on the stability of the complex.

\subsection{Complex Formation Equilibria Involving Peptides}

The potentiometric data for the peptide complexes were fitted on the basis of formation of the complexes with stoichiometric coefficients 110 and 11-1, as given in Eq. (5)

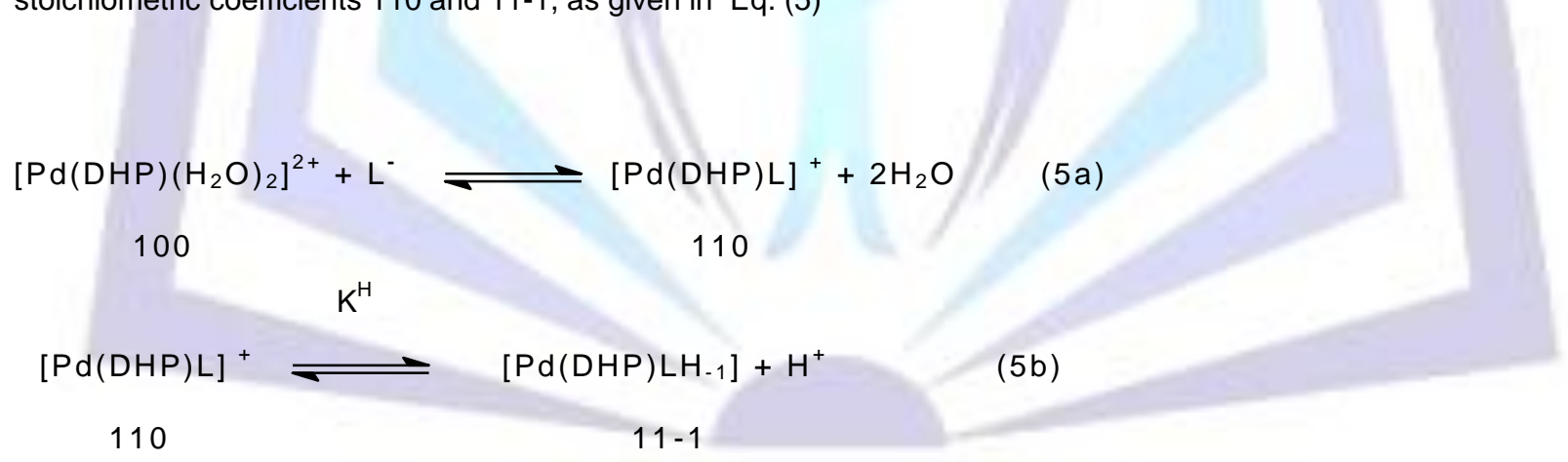

The 110 complex is formed via coordination of the amine and carbonyl groups. On increasing $\mathrm{pH}$, the amide groups undergo deprotonation associated with switch of coordination site from carbonyl to amide and the complex $\left[\mathrm{Pd}\left(\mathrm{DHP}\left(\mathrm{LH}_{-1}\right)\right],(11-1)\right.$ is formed. Such changes in coordination centres are well documented [ 26,27 ]. The pK $\mathrm{K}^{\mathrm{H}}$ of the amide groups incorporated in the $P d^{\prime \prime}$ complexes $\left(\log \beta_{110}-\log \beta_{11-1}\right)$ are in the 3.33-8.32 range. It is interesting to note that the $\mathrm{pK}_{\mathrm{a}}$ value for the glycinamide complex is lower than those for other peptides. This can be explained on the basis that the more bulky substituent on the peptide as in glycylleucine and glycylphenylalanine may hinder the structural changes when going from the protonated to the deprotonated complexes. Also, ethanolamine forms the complex species 110 and 11-1, and the $\log \beta 110$ value for ethanolamine is smaller than those for amino acids. This may be due to the coordination of ethanolamine at low $\mathrm{pH}$ through the amino group only. At higher $\mathrm{pH}$, the hydroxyl group undergoes induce ionization and participates in complex formation forming the species 11-1. The pKH value of the coordinated alcohol group in ethanolamine is 5.85 . The induce ionization occurs through coordination of the hydroxyl group. Due to the donation of the electron pair on the oxygen to the metal centre, the $\mathrm{OH}$ bond is considerably weakened and thus the ionization of the proton occurs at a lower $\mathrm{pH}$. 
The distribution diagram for the $\mathrm{Pd}(\mathrm{DHP})$-ethanolamine system is given in Fig. 1. $[\mathrm{Pd}(\mathrm{DHP}) \mathrm{L}]^{+}(110)$, starts to form at lower $\mathrm{pH}$, its concentration increases with increasing $\mathrm{pH}$ and reaches a maximum of $38 \%$ at $\mathrm{pH} 5.3$. A further increase in $\mathrm{pH}$ is accompanied by a decrease in $[\mathrm{Pd}(\mathrm{DHP}) \mathrm{L}]^{+}(110)$ concentration and an increase in $[\mathrm{Pd}(\mathrm{DHP}) \mathrm{LH}-1](11-1)$ concentration, reaching a maximum of $100 \%$ at pH 8.7 i.e. in the physiological pH range the deprotonated species (11-1) predominates.

Spectral bands of $\mathrm{Pd}(\mathrm{DHP})\left(\mathrm{H}_{2} \mathrm{O}\right)_{2}{ }^{2+}$ and its glycinamide complex are quite different in the position of the maximum wavelength and molar absorptivity. The spectrum of $\mathrm{Pd}(\mathrm{DHP})\left(\mathrm{H}_{2} \mathrm{O}\right)_{2}{ }^{2+}$ complex shows an absorption maximum at $354 \mathrm{~nm}$. On the other hand the spectrum obtained for $\mathrm{Pd}(\mathrm{DHP})$ (glycinamide) ${ }^{2+}(110$ species), (mixture B), exhibits a band at 304

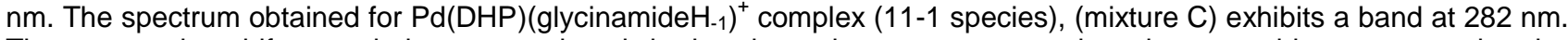
The progressive shift toward shorter wavelength in the absorption spectrum may be taken as evidence, supporting the potentiometric measurements for the induced ionization of amide upon complex formation.

\subsection{Complex Formation Equilibria Involving DNA Constituents}

DNA constituents such as inosine, guanosine and inosine-5'-monophosphate form 1:1 and 1:2 complexes with the $\mathrm{Pd}(\mathrm{DHP})^{2+}$ ion. However, inosine-5'-monophosphate forms the protonated complexes, in addition to the formation of $1: 1$ and 1:2 complexes. Inosine-5'-monophosphate forms the mono- and diprotonated complexes (111 and 112). The pKa values of the protonated species values are $4.61\left(\log \beta_{112}-\log \beta_{111}\right)$ and $6.84\left(\log \beta_{111}-\log \beta_{110}\right)$. The former pKa value corresponds to $\mathrm{N}_{1} \mathrm{H}$ group and the second pKa value to the $-\mathrm{PO}_{2}(\mathrm{OH})$ group. The $\mathrm{N}_{1} \mathrm{H}$ group was acidified upon complex formation by 4.11 pKa units. Acidification of the $\mathrm{N}_{1} \mathrm{H}$ group upon complex formation is consistent with previous reports for IMP complex [28]. The phosphate group was not acidified upon complex formation since it is far away formation is explained on the basis of possible hydrogen bonding between posphate group and exocyclic amine group [29].

The concentration distribution diagram for the $\mathrm{Pd}(\mathrm{DHP})^{2+}-\mathrm{IMP}$ system taken as a model for DNA binding , Fig. 2 , shows that in the physiological pH range the IMP complex (110) dominates with a maximum concentration of $69 \%$ and the hydrolysed species have no contribution, i.e. the interaction between $\mathrm{Pd}(\mathrm{DHP})^{2+}$ and IMP as a DNA constituent is feasible. The protonated species (112) exists in a concentration of $98 \%$ at $\mathrm{pH} 2.0$ and the species (111) predominates with the maximum concentration of $88 \% \%$ at $\mathrm{pH} 5.8$.

\subsection{Effect of chloride ion concentration on the equilibrium constants of inosine complex with $\left[\mathrm{Pd}(\mathrm{DHP})\left(\mathrm{H}_{2} \mathrm{O}\right)\right]^{2+}$}

The data of the effect of chloride ion concentration on the stability of $[\mathrm{Pd}(\mathrm{DHP})($ inosine)] complex was given in Table 3. The stability constant of the 1:1 complex in $\mathrm{Pd}(\mathrm{DHP})$-inosine system tends to decrease with increasing of [Cl]. This is accounted for on the basis that the concentration of the active species, the diaqua- complex, decrease on increasing $\left[\mathrm{Cl}^{-}\right]$, and this in turn will affect the stability of the complexes.

\subsection{Displacement reaction of coordinated inosine}

The preference of $\mathrm{Pd}(\mathrm{II})$ to coordinate to S-donor ligands was previously documented $[30,31]$. These results suggest that $\mathrm{Pd}(\mathrm{II})-\mathrm{N}$ adducts can easily be converted into $\mathrm{Pd}-\mathrm{S}$ adducts. Consequently, the equilibrium constant for such displacement reaction is of biological significance. Consider inosine as a typical DNA constituent (presented by HA) and mercaptoethylamine as a typical thiol ligand (presented by $\mathrm{H}_{2} \mathrm{~B}$ ). The equilibria involved in complex-formation and displacement reactions are:

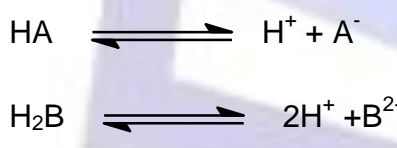

$[P d(D H P)]^{2+}+A^{-} \rightleftharpoons[P d(D H P) A]^{+}$ (5a)

$$
\square_{110}{ }^{[\mathrm{Pd}(\mathrm{DHP}) \mathrm{A}]+}=\left[\mathrm{Pd}(\mathrm{DHP}) \mathrm{A}^{+}\right] /\left[\mathrm{Pd}(\mathrm{DHP})^{2+}\right]\left[\mathrm{A}^{-}\right]
$$

$$
[\mathrm{Pd}(\mathrm{DHP})]^{2+}+\mathrm{B}^{2-} \rightleftharpoons[\mathrm{Pd}(\mathrm{DHP}) \mathrm{B}]
$$

$$
\begin{gathered}
\square_{110}{ }^{[\mathrm{Pd}(\mathrm{DHP}) \mathrm{B}]}=[\mathrm{Pd}(\mathrm{DHP}) \mathrm{B}] /\left[\mathrm{Pd}(\mathrm{DHP})^{2+}\right]\left[\mathrm{B}^{2-}\right] \\
\mathrm{K}_{\text {eq }}
\end{gathered}
$$


$[\operatorname{Pd}(\mathrm{DHP})(\mathrm{A})]^{+}+\mathrm{B}^{2-} \rightleftharpoons[\operatorname{Pd}(\mathrm{DHP})(\mathrm{B})]+\mathrm{A}^{-}$

The equilibrium constant for the displacement reaction given in eq. (8) is given by

$\mathrm{K}_{\text {eq }}=[\mathrm{Pd}(\mathrm{DHP})(\mathrm{B})]\left[\mathrm{A}^{-}\right] /\left[\mathrm{Pd}(\mathrm{DHP})(\mathrm{A})^{+}\right]\left[\mathrm{B}^{2-}\right]$

Substitution from eq. (6b) and (7b) in eq. (9) results in:

$\mathrm{K}_{\mathrm{eq}}=\beta_{110}{ }^{[\mathrm{Pd}(\mathrm{DHP}) \mathrm{B}] / \beta_{110}}{ }^{[\mathrm{Pd}(\mathrm{DHP}) \mathrm{A}]+}$

$\log \beta_{110}$ values for $[\mathrm{Pd}(\mathrm{DHP})(\mathrm{A})]^{+}$and $[\mathrm{Pd}(\mathrm{DHP}) \mathrm{B}]$ complexes taken from Table 1 amount to 6.24 and 12.61 , respectively, and by substitution in eq. (10) results in $\log \mathrm{K}_{\text {eq }}=6.37$. This value clearly indicates how sulfhydryl ligands such as mercaptoethylamine and by analogy glutathione are effective in displacing the DNA constituent, i.e., the main target in tumour chemotherapy.

\section{Conclusions}

$\mathrm{Pd}(\mathrm{DHP}) \mathrm{Cl}_{2}$ complex was synthesized and characterized. The interaction of $\left[\mathrm{Pd}(\mathrm{DHP})\left(\mathrm{H}_{2} \mathrm{O}\right)_{2}\right]^{2+}$ with some selected bio-relevant ligands was investigated. Comparing stability constants of $\mathrm{Pd}(\mathrm{II})$ complexes with these ligands, it would be possible to evaluate the speciation of $\mathrm{Pd}(\mathrm{II})$ complexes in biological fluid. This would form a clear basis for understanding the mode of action of such metal species under physiological conditions. The $\mathrm{pK}^{\mathrm{H}}$ of the amide groups incorporated in the Pd" complexes has interesting biological implications. Under normal physiological conditions (pH 6-7) the peptide would coordinate to $\left[\mathrm{Pd}(\mathrm{DHP})\left(\mathrm{H}_{2} \mathrm{O}\right)_{2}\right]^{2+}$ in entirely different fashions. Glycylphenylalanine would exist solely in the protonated form, whereas the other peptides would be present entirely in the deprotonated form. Therefore, the slight difference in the side chain of the peptides produces dramatic differences in their behaviour toward the palladium species. The equilibrium constant for displacement reaction of inoosine by mercaptoethylamine measures the deactivation of the $\mathrm{Pt} / \mathrm{Pd}$ based-drug by the sulphur containing biomolecules.

Antitumour $\mathrm{Pt}(\mathrm{II})$-amine complexes are usually administrated as cis-dichloro-complexes. This form persists in human blood plasma with its high $0.16 \mathrm{M} \mathrm{Cl}^{-}$ion content [32]. The net zero charge on the complex fasters its passage through cell walls. Within many cells the $\mathrm{Cl}^{-}$ion concentration is much lower, only $4 \mathrm{mM}$. Under this low chloride ion concentration, the reactivity of the $\mathrm{Pt}(\mathrm{II})$-amine complex increases. Therefore a realistic extrapolation of the present study to biologically relevant conditions will require investigating the effect of $\left[\mathrm{Cl}^{-}\right]$on the stability constant of the complexes

\section{REFERENCES}

[1] B. Rosenberg, L.VanCamp, J.E. Trosko, V.H. Mansour, Nature 222 (1969) 385.

[2] B. Lippert. Cisplat.in. Chemistry and Biochemistry of a leading Anticancer Drug, ed. B. Lippert, Wiley-VCH, Zurich, 1999.

[3] N.J. Wheate, S. Walker, G.E. Craig, R. Oun. ,Dalton Trans., 39 (2010) 8113.

[4] L.R. Kelland, Nat. Rev. Cancer, 7 (2007) 573.

[5] E. Wong , C.M. Giandomenico, Chem. Rev., 99 (1999) 2451.

[6] A. Eastman, N. Schule Biochemistry 27 (1988) 4730.

[7] A.M.J. Fichtinger-Schepman, J.L. van der Veer, J.H.J. den Hartog, P.H.M. Lohman, J. Reeddijk, Biochemistry 24 (1985) 707.

[8] Y.W. Jung, S.J. Lippard, Chem. Rev. 107 (2007) 1387.

[9] A.. Shoukry, T. Rau, M. Shoukry, R. van Eldik, J. Chem. Soc. Dalton Trans., (1998) 3105.

[10] M.R. Shehata, M.M. Shoukry, F.M. Nasr, R. van Eldik, Dalton Trans., (2008) 779.

[11] Z.D. Bugarcic , M.M. Shoukry, R. van Eldik , J. Chem. Soc. Dalton Trans., (2002) 3945.

[12] A.A. El-Sherif, M.M. Shoukry, R. van Eldik, J. Chem. Soc. Dalton Trans., (2003) 1425.

[13] M.M. Shoukry, H. Hohmann, R. van Eldik, Inorg. Chim. Acta, 198 (1992) 187.

[14] M.M.A. Mohamed, M.M. Shoukry, Polyhedron, 20 (2001) 243.

[15] M.M.A. Mohamed, M.M. Shoukry, Polyhedron, 21 (2002) 167 .

[16] M. Odoke, N. Okabe, Acta Crystallogr. Sec., 62 (2006) 136.

[17] R. Ranaldo, N. Margiotta, F.P. Intini, C. Pacifico, G. Natile, Inorg. Chem., 47 (2008) 2820.

[18] J.D. Hoeschele, H.D.H. Showalter, A.J. Kraker, W.L. Elliot, B.J. Roberts, J.W. Kampf, J. Med. Chem., 37 (1994) 2630.

[19] R.G. Bates "Determination of pH-Theory and Practice", $2^{\text {nd }}$ Edit., Wiley-Interscience, New York ,1975. 
[20] Chemistry Data Book, Eds. J. G. Stark, H. G. Wallace, Murray, London , p. 1975 , p.75.

[21] P. Gans , A. Sabatini , A. Vacca , Inorg. Chim. Acta, 18 (1976) 237.

[22] L. Pettit, University of Leeds, Personal Communication.

[23] D. D. Perrin, Stability Constants of Metal-Ion Complexes: Part B Organic Ligands, Pergamon Press, Oxford, 1979.

[24] M.M. Shoukry, W.M. Hosny and M.M. Khalil, Transition Met. Chem., 20 (1995) 252.

[25] A.A. El-Sherif, J. Solution Chem., 35 (2006) 1287.

.[26] H. Sigel, R.B. Martin, Chem.Rev. 82 (1982) 385.

[27] M.C. Lim , J. Chem. Soc. Dalton Trans., 1 (1977) 15.

[28] M.A. Jakupec, M. Galanski, V.B. Arion, C.G. Hartinger, B.K. Keppler, Dalton Trans., (2008) 183.

[29] M.M. Shoukry, A. Al-Najjar, W.M. Hosny, A.E. Mahgoub, A.K. Abdelhadi and P.A. Khalf-Alla, J. Sulfur Chem., 32 (2011) 563.

[30] S. Hochreuther, S.N. Nadibewour, R. Puchta, R. Van Eldik, Dalton Trans., 41 (2012) 512.

[31] G. Bogdanovic, V. Kojic, T. Sradic, D. Jakimov, M. Djuran, Z.D. Bugarcic, M. Baltic, V.V. Baldic, Met.-Based Drugs, 9 (2002) 33.

Table 1. Formation constant of $\mathrm{M}_{\mathrm{p}} \mathrm{L}_{\mathrm{q}} \mathrm{H}_{\mathrm{r}}$ species in aqueous solution at $25 \pm 0.1{ }^{\circ} \mathrm{C}$ and $\mathrm{I}=0.1 \mathrm{~mol}-\mathrm{dm}^{-3}\left(\mathrm{NaNO}_{3}\right)$.

\begin{tabular}{|c|c|c|c|c|c|}
\hline System & $p$ & $q$ & $r^{a}$ & $\log \beta^{b}$ & $S^{c}$ \\
\hline \multirow[t]{2}{*}{$\mathrm{Pd}(\mathrm{DHP})\left(\mathrm{OH}_{2}\right)_{2}$} & 1 & 0 & -1 & $-5.61(0.01)$ & $1.1 \mathrm{E}-7$ \\
\hline & 1 & 0 & -2 & $10.00(0.00)$ & \\
\hline \multirow[t]{3}{*}{ Phenylglycine } & 0 & 1 & 1 & $9.01(0.01)$ & $3.4 \mathrm{E}-8$ \\
\hline & 0 & 1 & 2 & $11.47(0.01)$ & \\
\hline & 1 & 1 & 0 & $9.80(0.02)$ & 4.2E-7 \\
\hline Phenylalanine & 0 & 1 & 1 & $9.12(0.01)$ & $7.5 \mathrm{E}-8$ \\
\hline \multirow[t]{2}{*}{ Valine } & 0 & 1 & 1 & $9.64(0.01)$ & $6.7 \mathrm{E}-8$ \\
\hline & 1 & 1 & 0 & $10.49(0.01)$ & $9.5 \mathrm{E}-8$ \\
\hline \multirow[t]{4}{*}{ Threonine } & 0 & 1 & 1 & $9.06(0.01)$ & 2.7E-7 \\
\hline & 0 & 1 & 2 & $11.03(0.02)$ & \\
\hline & 1 & 1 & 0 & $9.12(0.02)$ & 2.1E-7 \\
\hline & 1 & 1 & -1 & $0.41(0.03)$ & \\
\hline \multirow[t]{4}{*}{ Lysine } & 0 & 1 & 1 & $10.44(0.01)$ & $1.4 \mathrm{E}-8$ \\
\hline & 0 & 1 & 2 & $19.66(0.01)$ & \\
\hline & 1 & 1 & 0 & $10.39(0.03)$ & $5.1-8$ \\
\hline & 1 & 1 & 1 & $20.30(0.02)$ & \\
\hline
\end{tabular}




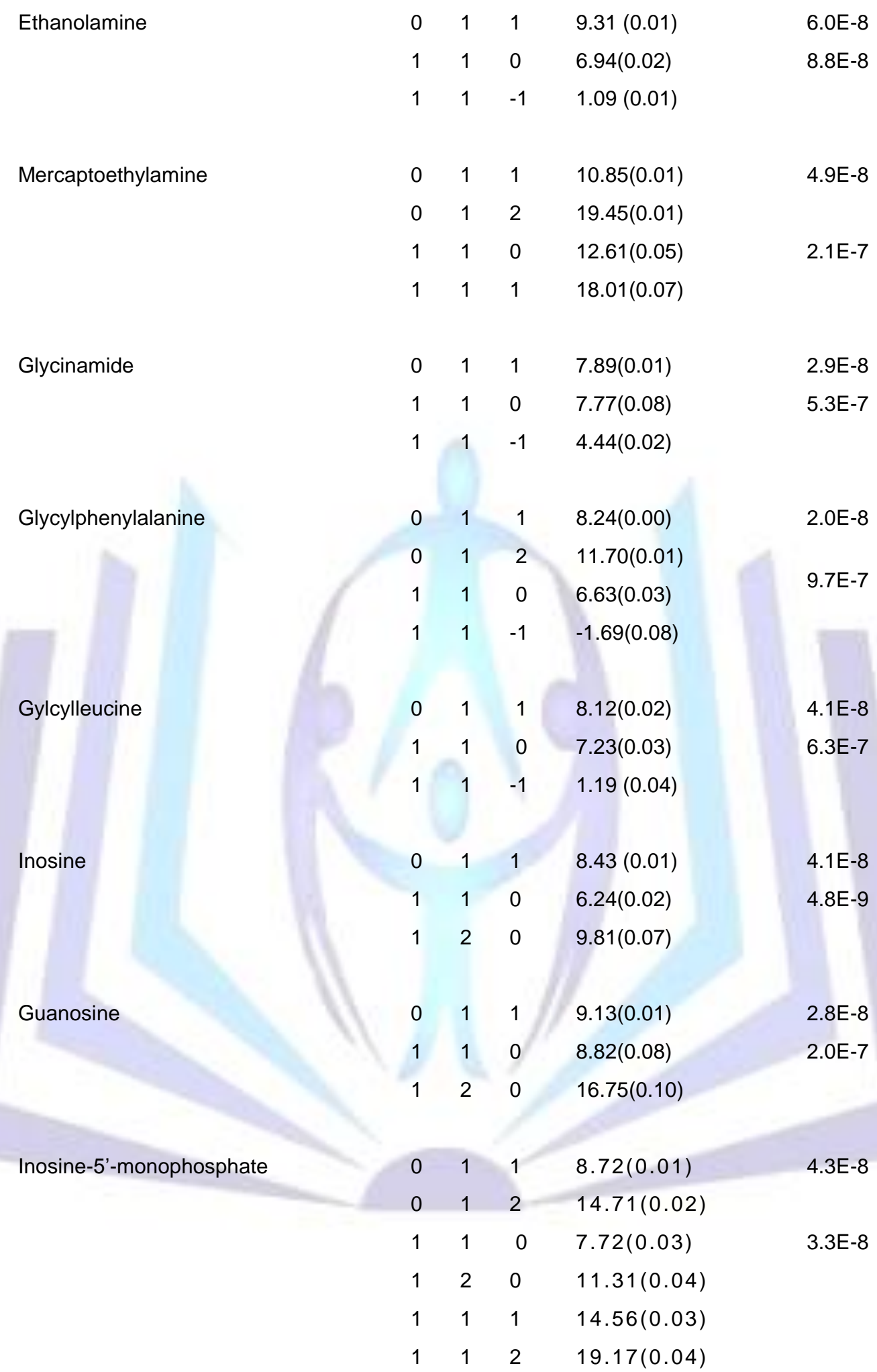

${ }^{a} p, q$ and $r$ are the stoichiometric coefficients corresponding to $\mathrm{Pd}(\mathrm{DHP})^{2+}$, (amino acid, dicarboxylic acid, peptide or DNA) and $\mathrm{H}^{+}$, respectivelyStandard deviations are given in parentheses, ${ }^{\circ}$ Sum of square of residuals. 
Table 2. Effect Chloride Ion Concentration on the formation constant of $\mathrm{Pd}(\mathrm{DHP})$-Inosine complex at $25{ }^{\circ} \mathrm{C}$ and $0.30 \mathrm{M}$ ionic strength.

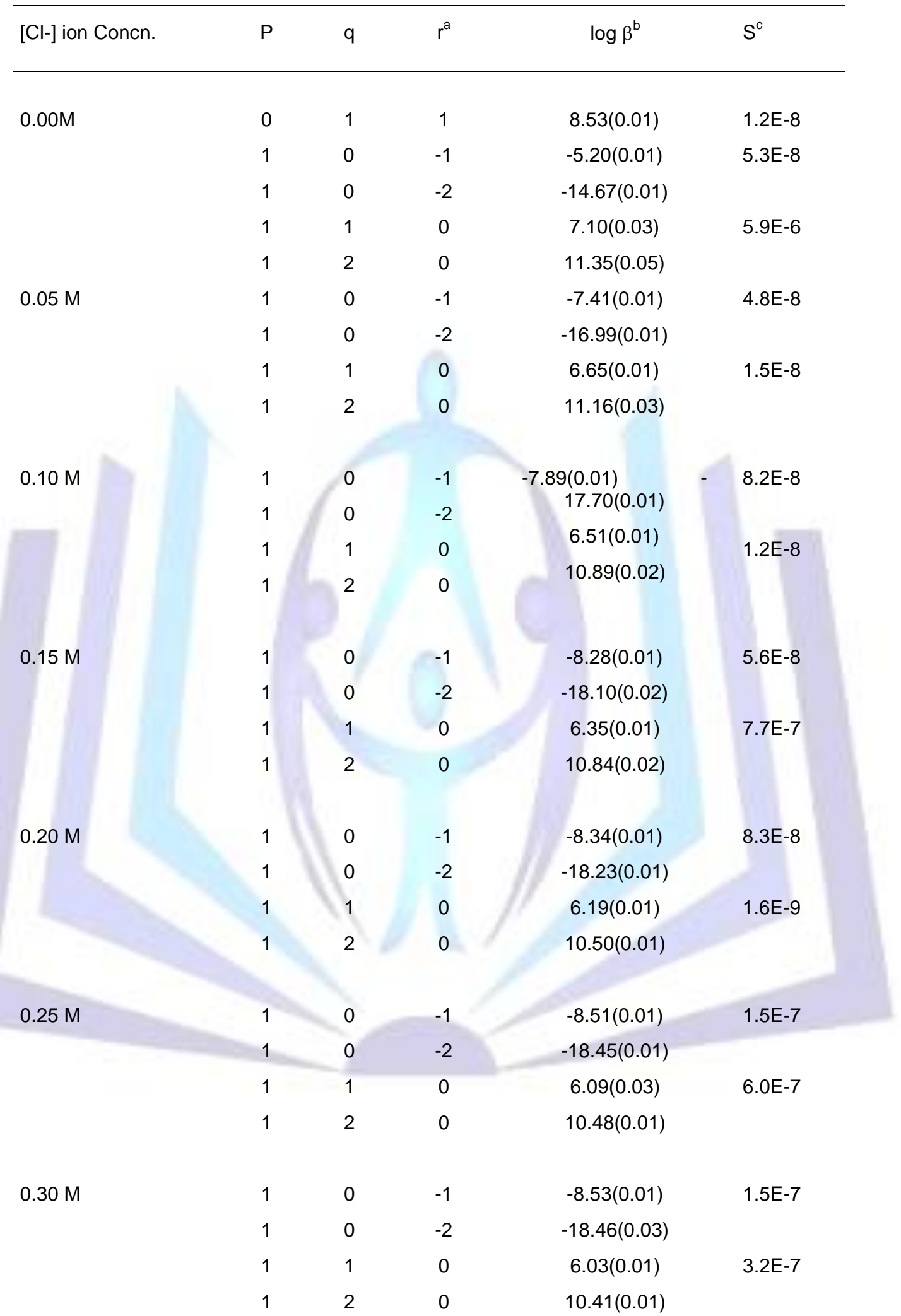

${ }^{a} p, q$ and $r$ are the stoichiometric coefficients corresponding to $\mathrm{Pd}(\mathrm{DHP})$, Inosine and $\mathrm{H}^{+}$

respectively. 


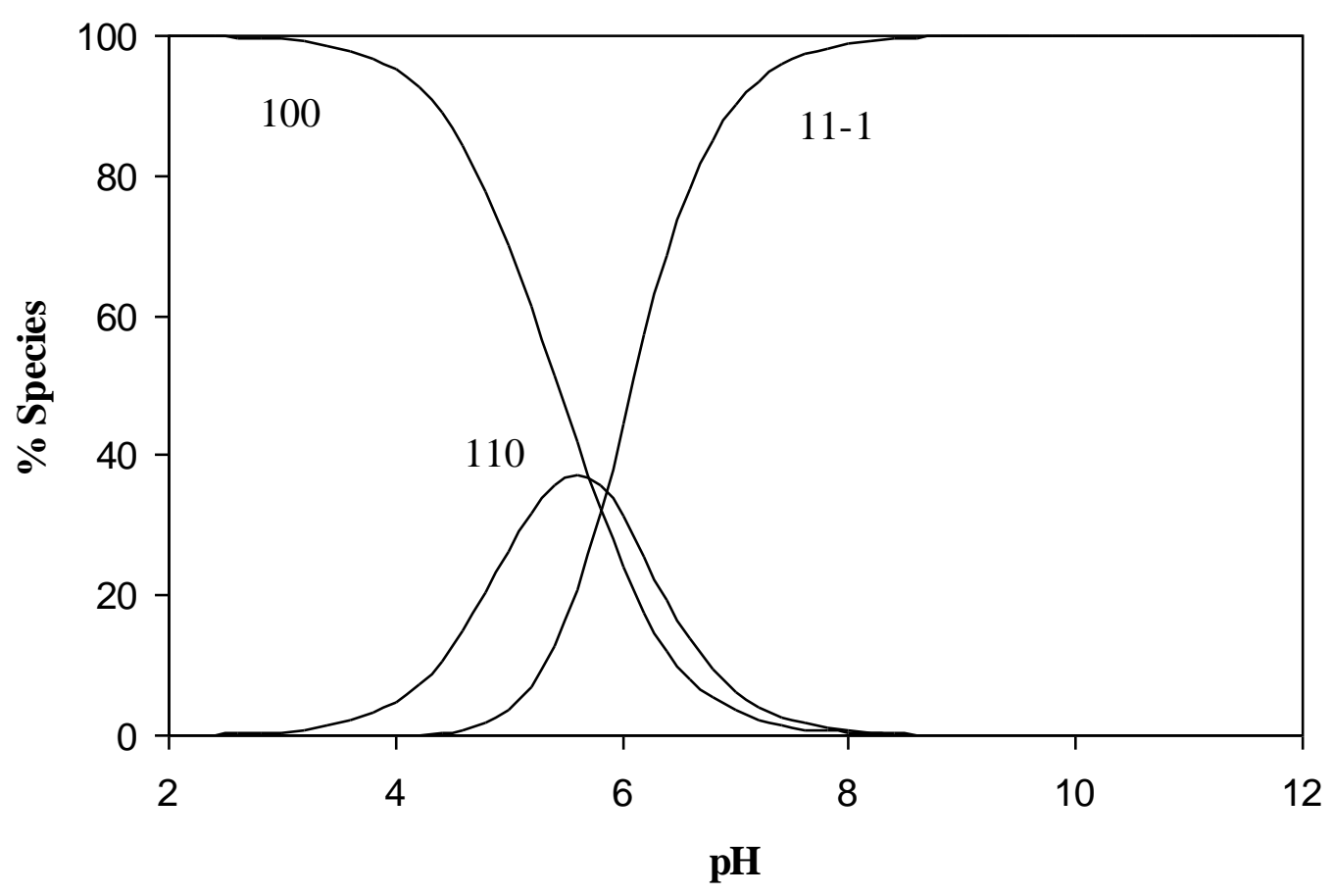

Fig. 1. Concentration distribution of various species as a function of $\mathrm{pH}$ in the $\mathrm{Pd}(\mathrm{DHP})^{2+}$-ethanolamine system

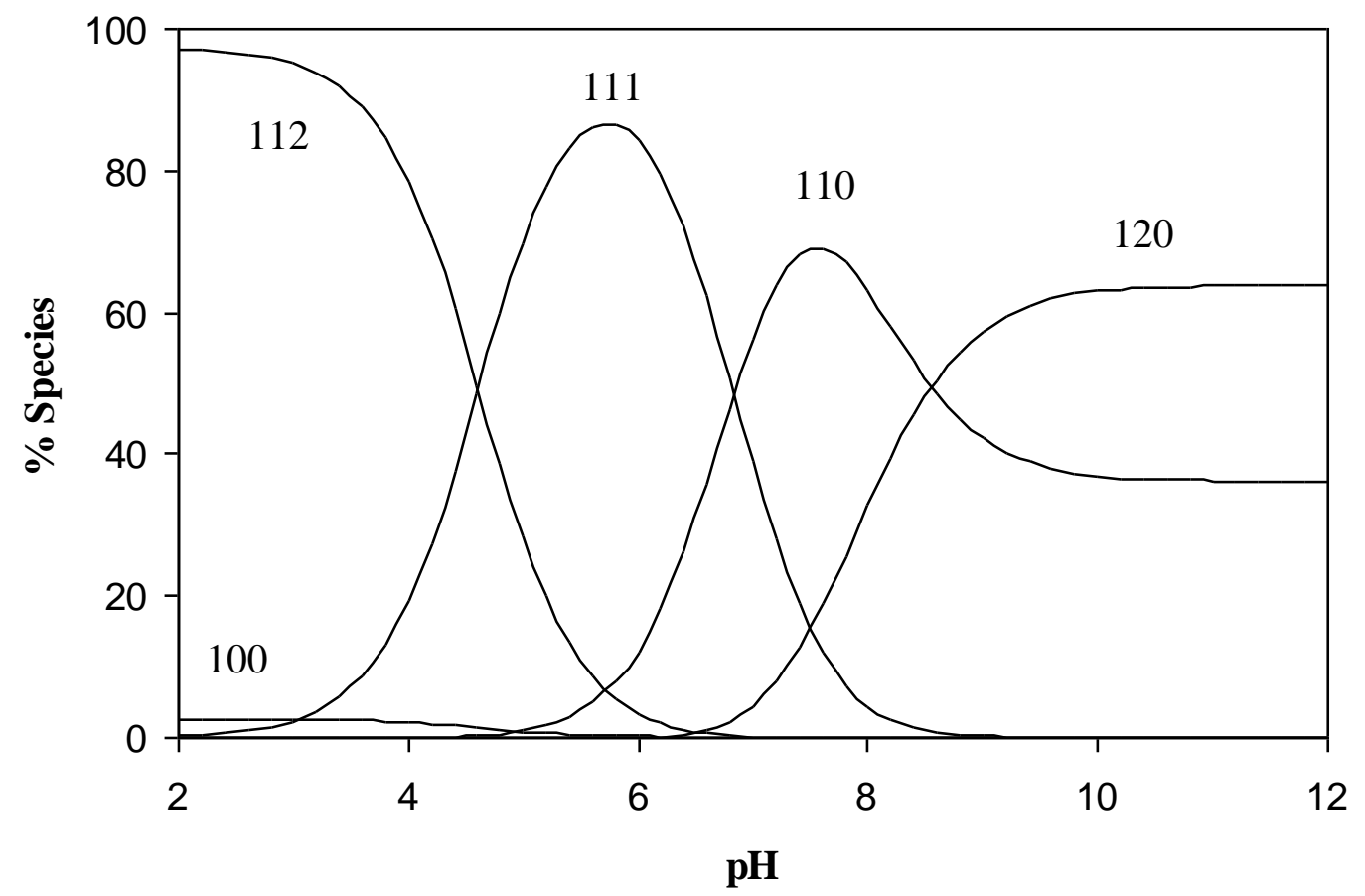

Fig. 2. Concentration distribution of various species as a function of $\mathrm{pH}$ in the $\mathrm{Pd}(\mathrm{DHP})^{2+}-$ IMP system. 